\title{
Topical Route of Administration
}

National Cancer Institute

\section{Source}

National Cancer Institute. Topical Route of Administration. NCI Thesaurus. Code C38304.

The application of a drug to a certain area of the skin or mucous membrane (including the intra-organ application), or other tissue locally, so that the agent will take effect on the surface and/or on the underlying tissues. 